\title{
Dampak Suplementasi Besi dan Seng dalam Meningkatkan Eritropoiesis pada Malaria Anak yang Diheri Ohat Anti Malaria di Daerah Endemis
}

\author{
Bidasari Lubis \\ Divisi Hematologi Onkologi Bagian Ilmu Kesehatan Anak Fakultas Kedokteran Universitas Sumatera Utara/ \\ RS H Adam Malik, Medan
}

\begin{abstract}
Latar belakang. Dampak besi dan seng untuk anak pasien malaria pada daerah endemis telah diteliti dapat menurunkan parasitemia. Namun penelitian interaksi keduanya bila diberikan bersama-sama untuk meningkatkan kadar hemoglobin, serum feritin, dan retikulosit masih terbatas.

Tujuan. Membandingkan dampak seng dalam meningkatkan absorbsi besi pada anak dengan malaria falciparum yang mendapat pengobatan.

Metode. Subjek dibagi menjadi dua kelompok yaitu kelompok besi ditambah plasebo dan kelompok besi ditambah seng kemudian darah vena diambil sebelum perlakuan (H0) dan pada akhir penelitian (H30).

Hasil. Setelah 30 hari suplementasi, 69 anak dapat menyelesaikan penelitian dan memenuhi kriteria untuk dapat dianalisis. Terdapat perubahan yang bermakna pada konsentrasi hemoglobin kelompok besi ditambah plasebo dan kelompok besi ditambah seng setelah suplementasi (0,58 dan 0,09 $\mathrm{g} / \mathrm{dl} ; \mathrm{p}<0,05)$ tetapi serum feritin dan retikulosit tidak bermakna.

Kesimpulan. Suplementasi besi dan seng hanya meningkatkan kadar hemoglobin pada anak penderita malaria di daerah endemis yang diberi obat anti malaria (Sari Pediatri 2008;10(1):1-7).
\end{abstract}

Kata Kunci: besi, seng, eritropoiesis, malaria

A nemia defisiensi besi terdapat pada hampir setengah dari seluruh anak dan wanita hamil pada negara berkembang dan lebih dari 500 juta kasus anemia ada di seluruh dunia.

\footnotetext{
Alamat Korespondensi:

Prof. Dr. Bidasari Lubis, SpA(K). Bagian Ilmu Kesehatan Anak FK USU/

RS HAM Jalan Bunga Lau No. 17 Telepon : (061) 8361721, Fax: (061)

8361721. E-mail: bikafkusu@telkom.net; kotak Pos 697 Medan-20136
}

Anemia defisiensi besi pada daerah endemis malaria akan menyebabkan kematian terutama pada anak dan ibu hamil. ${ }^{1}$ Anak di bawah 5 tahun di daerah endemis malaria juga akan berisiko untuk menderita malnutrisi energi protein serta defisiensi mikronutrien termasuk seng. ${ }^{2}$

Defisiensi besi yaitu berkurangnya total kandungan besi dalam tubuh yang dibagi dalam 3 tahap. Gangguan keseimbangan besi akan menyebabkan deplesi besi ditandai dengan total besi dalam tubuh berkurang 
tetapi tidak mempengaruhi sintesis hemoglobin. Bila asupan besi pada sumsum tulang tidak adekuat maka akan terjadi tahap berikutnya yaitu defisiensi besi pada eritropoesis. Akhirnya jika besi sangat kurang untuk mempertahankan konsentrasi hemoglobin yang normal maka akan timbul anemia defisiensi besi. ${ }^{3}$

Terdapat beberapa bukti bahwa parasitemia yang menetap dan berulang menyebabkan defisiensi besi walaupun mekanismenya masih belum jelas, tetapi diduga, 1 . Terdapat penurunan absorbsi besi pada fase akut penyakit. 2. Kadar haptoglobin yang rendah, karena adanya hemolisis intravaskular, yang akan mengurangi pembentukan kompleks haptoglobin/ hemoglobin serta penurunan penggunaan besi. 3 . Terjadinya immobilisasi besi di dalam kompleks hemazoin (pigmen malaria). ${ }^{4}$

Masukan seng dapat mempengaruhi proses masuknya atau pelepasan besi dari feritin. ${ }^{5}$ Pada keadaan normal, seng seperti juga besi akan bergabung dengan besi selama tahap akhir biosintesis heme. ${ }^{6}$ Pada saat terjadi defisiensi besi, protoporfirin IX tidak dapat bergabung dengan besi untuk membentuk heme pada tahap akhir sistesis heme. Akibat tidak adanya besi, protoporfirin bergabung dengan seng untuk membentuk free erythrocyte zinc protoporphyrin (ZPP) yang stabil selama hidup sel darah merah. ${ }^{7}$

Verhoef H dkk, ${ }^{8}$ menyimpulkan bahwa suplementasi besi tidak berhubungan dengan risiko efek samping malaria. Lind T dkk. ${ }^{9}$ pada penelitian yang dilakukan pada anak di Jawa Tengah, menemukan bahwa efek suplementasi gabungan antara besi dan seng terbukti kurang efikasinya dibandingkan suplementasi tunggal dalam meningkatkan status besi dan seng. ${ }^{9}$
Pada penelitian kami akan membuktikan dampak suplementasi besi dan seng dalam meningkatkan eritropoiesis pada malaria anak di daerah endemis yang diberi obat anti malaria.

\section{Metode}

Subjek dimasukkan ke dalam kelompok perlakuan yaitu besi ditambah plasebo atau besi ditambah seng. Besi diberikan setiap hari dalam bentuk sirup sulfa ferosus dengan dosis $6 \mathrm{mg}$ besi elemental per kilogram berat badan (sulfa ferosus $26,25 \mathrm{mg} / 5 \mathrm{ml}$, Iberet $500^{\circledR}$, Abbott Indonesia). Seng diberikan setiap hari sebagai kapsul yang mengandung $10 \mathrm{mg}$ zinc sulfat (seng elemental 10 mg/kapsul, Novell Indonesia ${ }^{\circledR}$ ). Kapsul yang mengandung seng dan plasebo mempunyai bentuk dan rasa yang sama. Semua anak diberi klorokuin base $10 \mathrm{mg}$ per kilogram berat badan pada hari pertama diikuti dengan $5 \mathrm{mg}$ per kilogram berat badan delapan jam kemudian dan selanjutnya $5 \mathrm{mg}$ per kilogram berat badan setiap hari untuk hari ke dua dan ketiga.

Darah vena diambil tiga mililiter dari sampel penelitian sebelum dan setelah 30 hari suplementasi. Kemudian dilakukan pemeriksaan hemoglobin, hematokrit, eritrosit, mean corpuscular volume $(M C V)$, mean corpuscular hemoglobin concentration $(\mathrm{MCHC})$, retikulosit, dan ferritin serum. Konsentrasi hemoglobin, hematokrit, eritrosit, MCV, MCHC, diukur dengan auto analyzer (ABX Mikros 60, France), dan serum feritin dengan immunoessay (Vidas, Biomeureux). Subjek ditimbang dan dinilai berat badan dengan menggunakan timbangan merk

Tabel 1. Karakteristik klinis dan laboratorium (sebelum suplementasi)

\begin{tabular}{cccccc}
\hline Karakteristik & \multicolumn{2}{c}{ Besi ditambah plasebo } & \multicolumn{2}{c}{ Besi ditambah seng } & \multirow{2}{*}{$\mathrm{p}$} \\
\cline { 2 - 4 } & $\mathrm{n}$ & $\%$ & $\mathrm{n}$ & $\%$ & \\
\hline Umur (tahun) & & & & & \\
$0-<5$ & 16 & 36,4 & 15 & 35,7 & 0.92 \\
$5-<10$ & 15 & 34,1 & 13 & 31,0 & \\
$10-<15$ & 13 & 29,5 & 14 & 33,3 & \\
Jenis kelamin & & & & & \multirow{2}{*}{0,29} \\
Laki-laki & 26 & 59,1 & 19 & 45,2 & \\
Perempuan & 18 & 40,9 & 23 & 54,8 & \\
Status nutrisi & & & & & \\
Gizi buruk & 1 & 2,3 & 3 & 7,1 & \\
Gizi kurang & 4 & 9,1 & 9 & 21,4 & \\
Gizi baik & 33 & 75,0 & 23 & 4,8 & \\
Overweight & 6 & 13,6 & 7 & 4,2 & \\
\hline
\end{tabular}


MIC (sensitif sampai $0,5 \mathrm{~kg}$ ) dan tinggi badan diukur dengan pengukur tinggi merk MIC (sensitif sampai $0,5 \mathrm{~cm}$ ). Status nutrisi dihitung dengan tehnik antropometri standar berdasarkan CDC NCHSWHO. ${ }^{10}$

Besar subjek minimal 32 anak pada setiap kelompok dan data diolah dengan SPSS for Windows 10 (SPSS Inc, Chicago). Analisa data untuk karakteristik sampel, karakteristik hasil laboratorim sebelum suplementasi, dan hasil apusan darah tepi setelah suplementasi dengan uji chi square. Uji kenormalan dilakukan dengan Kolmogorov Smirnov, bila data berdistribusi normal digunakan uji $t$ dependen sedangkan data yang berdistribusi tidak normal digunakan Wilcoxon Signed Ranks Test. Uji dinyatakan bermakna bila $p<0,05$.

\section{Hasil}

Selama periode penelitian terdapat 86 anak yang dibagi menjadi dua kelompok yaitu 44 anak untuk kelompok besi ditambah plasebo dan 42 anak kelompok besi ditambah seng. Setelah suplementasi hanya 69 anak yang menyelesaikan penelitian sampai akhir selama 30 hari. Tidak ada perbedaan bermakna pada umur, jenis kelamin, dan status nutrisi kedua kelompok sampel yang mendapat besi ditambah plasebo dan besi ditambah seng pada karakteristik data laboratorium sebelum suplementasi (Tabel 1). Kedua kelompok sampel tidak berbeda bermakna pada hasil laboratorium sebelum suplementasi (Tabel 2). Hemoglobin, hematokrit, dan MCV berbeda bermakna pada kelompok besi ditambah plasebo, eritrosit dan MCV berbeda bermakna pada kelompok besi ditambah seng setelah 30 hari suplementasi (Tabel 3). Di antara kedua kelompok hanya enam anak dari kelompok besi ditambah plasebo dan enam anak dari kelompok besi ditambah seng yang masih positif Plasmodium falciparum pada apusan darah tepinya setelah 30 hari suplementasi (Tabel 4).

Tabel 2. Karakteristik hasil laboratorium sebelum suplementasi

\begin{tabular}{lccc}
\hline \multicolumn{1}{c}{ Hemogram } & $\begin{array}{c}\text { Besi ditambah } \\
\text { plasebo }\end{array}$ & Besi ditambah seng & \multirow{2}{*}{$\mathrm{p}$} \\
\cline { 2 - 3 } & Rerata (SB) & Rerata (SB) & \\
\hline Hemoglobin (g/dl) & $11.3(1.0)$ & $11.4(1.1)$ & 0.54 \\
Hematokrit $(\%)$ & $33.9(2.9)$ & $33.5(5.6)$ & 0.67 \\
Eritrosit (juta/mm $)$ & $4.7(0.4)$ & $4.6(0.4)$ & 0.53 \\
MCV (f) & $71.7(4.9)$ & $73.4(6.4)$ & 0.17 \\
MCHC (g/dl) & $33.2(1.6)$ & $33.5(1.1)$ & 0.42 \\
Serum feritin (ng/mL) & $106.8(187.5)$ & $174.4(281.6)$ & 0.21 \\
Retikulosit $(\%)$ & $0,9(0,5)$ & $0,9(0,5)$ & 0,21 \\
\hline
\end{tabular}

${ }^{*} p<0,05$

Table 3. Hasil laboratorium sebelum dan sesudah suplementasi

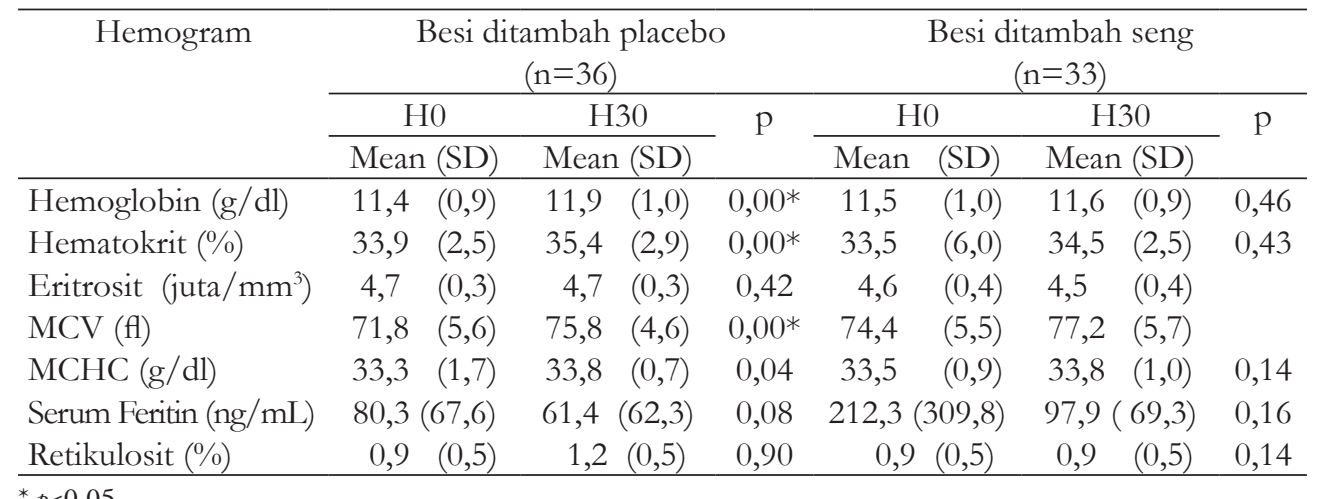
${ }^{*} p<0,05$ 
Bidasari Lubis: Suplementasi Besi dan Seng Meningkatkan Eritropoiesis pada Malaria

Tabel 4. Apusan darah tepi setelah 30 hari suplementasi

\begin{tabular}{lcccccc}
\hline \multirow{2}{*}{ Plasmodium falciparum } & \multicolumn{2}{c}{ Besi ditambah plasebo } & \multicolumn{2}{c}{ Besi ditambah seng } & \multicolumn{2}{c}{ Jumlah } \\
\cline { 2 - 7 } & $\mathrm{n}$ & $\%$ & $\mathrm{n}$ & $\%$ & $\mathrm{n}$ & $\%$ \\
\hline Negatif & 30 & 83,3 & 27 & 81,8 & 57 & 82,6 \\
Positif & 6 & 17,4 & 6 & 18,2 & 12 & 17,4 \\
Jumlah & 36 & 100,0 & 33 & 100,0 & 69 & 100,0 \\
\hline$p=0.8$ & $\mathrm{df}=1$ & & & & &
\end{tabular}

\section{Diskusi}

Infeksi dapat menyebabkan gangguan pertumbuhan dan malnutrisi sehingga menyebabkan anoreksia kekurangan nutrien dan perubahan metabolisme. Malnutrisi energi protein dan defisiensi mikronutrien seperti besi, vitamin A dan seng akan menyebabkan gangguan kekebalan tubuh. ${ }^{11}$

Anak kurang gizi cenderung untuk menderita malaria yang disebabkan oleh bermacam faktor terutama karena penurunan fungsi dari sistem imun sehingga tidak mempunyai kekebalan yang adekuat terhadap parasit malaria karena penurunan limfosit $\mathrm{T}$, gangguan formasi antibodi, penurunan formasi komplemen, dan atropi timus serta jaringan limfoid lain. ${ }^{12}$ Penelitian-penelitian terdahulu membuktikan adanya efek protektif pada keadaan kurang gizi terhadap morbiditas dan mortalitas akibat malaria. Ada beberapa penelitian yang dilakukan, mendapatkan bahwa pasien yang menderita malaria klinis dengan densitas parasit yang tinggi ternyata perbandingan berat badan terhadap umur cenderung berada di atas persentil ke-10 dibandingkan dengan pada yang densitas parasitnya rendah. Selain itu terdapat peningkatan serangan malaria klinis termasuk komplikasi serebral pada pengungsi yang menderita kurang gizi setelah dilakukan perbaikan gizi. ${ }^{13}$

Situasi lain mendapatkan malaria lebih sering ditemukan pada populasi yang kurang gizi dibanding yang gizinya baik, hal ini mungkin disebabkan oleh faktor lain sebagai pengganggu yaitu faktor sosial ekonomi yang rendah. Peneliti di Gambia tidak menemukan bahwa indeks antropometri berhubungan secara bermakna dalam menentukan kecenderungan menderita malaria pada tingkat komunitas. ${ }^{13}$

Pada penelitian ini ternyata sebagian besar anak mempunyai status gizi baik bila dilihat berdasarkan tinggi badan per umur bahkan ada yang status gizinya overweight. Hal ini sesuai dengan penelitian-penelitian pendahuluan yang dilakukan di daerah endemis malaria di Afrika, ternyata anak-anak yang mempunyai status gizi baik yang lebih banyak menderita malaria bila dibandingkan dengan yang mempunyai status gizi ringan, sedang, dan berat.

Manurut Shankar AH dkk, ${ }^{14}$ penyebab malnutrisi ringan sampai sedang di negara tropis oleh karena multifaktorial, bukan hanya berhubungan dengan diet yang tidak adekuat tetapi juga karena infeksi yang berulang. Hubungan antara malaria dan malnutrisi adalah penting, jika malaria adalah penyebab utama dari malnutrisi maka akan menyebabkan morbiditas yang tidak langsung dan cenderung untuk membaik bila malaria sudah terkontrol.

Lokasi penelitian ini berada pada ibukota kecamatan sehingga kesadaran akan gizi sudah relatif baik maka penyebab malnutrisi pada sampel penelitian mungkin karena penyakit malaria yang diderita. $P$ falciparum segera diterapi dengan klorokuin sehingga status gizi dapat meningkat bila penyakitnya teratasi. Anak dengan kadar hemoglobin rendah normal ( $\mathrm{Hb} 11,0$ $11,4 \mathrm{~g} / \mathrm{dl}$ ) akan menunjukkan respon terapeutik terhadap besi dengan peningkatan konsentrasi hemoglobin 1,0 g/dl atau lebih. ${ }^{15}$ Pada penelitian ini, terdapat perubahan yang bermakna pada kadar hemoglobin setelah diberikan besi ditambah plasebo. Ketika kadar hemoglobin dan hematokrit berada di bawah batas terendah, diagnosis anemia yang responsif terhadap besi sudah harus dipertimbangkan. Adanya nilai $\mathrm{MCV}$ dan/atau $\mathrm{MCH}$ lebih cenderung kepada anemia karena defisiensi besi, ${ }^{16}$ kecuali pada anemia yang disebabkan oleh infeksi, infeksi kronis, talasemia mayor, dan keracunan timbal. ${ }^{17}$ Hanya MCV yang meningkat secara bermakna setelah suplementasi pada kedua kelompok penelitian. Jika terjadi anemia maka produksi eritropoitin akan meningkat sehingga merangsang eritropoiesis dengan melepas retikulosit 
dari sumsum tulang ke darah perifer lebih cepat dari biasa. Retikulosit muda yang besar biasanya berada di sumsum tulang 2-3 hari sebelum dikeluarkan dari sumsum tulang di bawah rangsangan kadar eritropoitin yang lebih tinggi. ${ }^{18,19}$

Malaria menyebabkan perubahan distribusi besi dari penyimpanan. Konsentrasi serum besi, iron binding capacity dan saturasi serum transferin semuanya menurun, tetapi kebalikannya pada defisiensi besi kosentrasi serum feritin meningkat, hitung retikulosit normal atau meningkat. Hitung retikulosit digunakan untuk menilai kecepatan reaksi sumsum tulang terhadap anemia. Setelah pengobatan respon retikulosit dapat dilihat dalam 48-72 jam, dengan respon maksimal hari ke 5-10. ${ }^{20}$ Pada penelitian kami, retikulosit meningkat sedikit setelah pemberian suplementasi besi tapi tidak berbeda bermakna dan tanpak nilainya lebih tinggi pada pada pemberian besi ditambah plasebo.

Infeksi, inflamasi, dan penyakit keganasan menyebabkan kerusakan pada mukosa sehingga dapat menyebabkan peningkatan kecepatan sintesis di retikuloendotelial sistem dan terjadi peningkatan konsentrasi serum feritin. ${ }^{21}$ Infeksi akibat parasit malaria akan menyebabkan turunnya kadar hemoglobin sehingga terjadi anemia akibat defisiensi besi sedangkan kadar serum feritin akan mengalami peningkatan. Stoltzfus $\mathrm{dkk} .{ }^{22}$ pada penelitian di Zanzibar memperoleh kesimpulan bahwa terdapat peningkatan nilai feritin pada densitas parasit $>1000$ parasit $/ \mu \mathrm{L}$ dan mengalami penurunan 90 hari setelah pengobatan. ${ }^{22}$ Kadar serum feritin kedua kelompok tinggi sebelum intervensi tetapi kemudian mengalami penurunan setelah 30 hari suplementasi walaupun masih dalam batas normal. Hal ini terjadi karena anak yang positif Plasmodium Falciparum pada apusan darah tepinya telah diberi pengobatan dengan klorokuin.

Mekanisme di atas menunjukkan suatu anemia karena infeksi kronis dan gangguan inflamasi dengan karakteristik berikut ini 1 . Anemia ringan sampai sedang. 2. Penurunan umur sel darah merah. 3. Peningkatan serum iron dan iron binding capacity. 4. Peningkatan cadangan besi di jaringan dan serum feritin. 5. Penurunan sideroblas sumsum tulang. 6 . Peningkatan free erythrocyte protoporfirin. 7. Relative bone marrow unresponsiveness. ${ }^{23}$

Anemia pada infeksi kronis biasanya ringan dan disebabkan oleh penekanan yang terus menerus pada produksi eritropoetin dan kemampuan sel progenitor eritroid untuk berproliferasi sebagai respon terhadap eritropoetin. Kedua efek ini kemungkinan disebabkan oleh sitokin proinflamatori seperti tumor necrosis factor (TNF) dan interleukin-1 (IL-1). ${ }^{11}$

Zinc protoporphyrin (ZPP) merupakan metabolit normal yang dibentuk oleh protoporfirin dan seng pada biosintesis heme. Reaksi akhir dari jalur biosintesis heme adalah ikatan antara besi dan protoporfirin, bila terjadi kekurangan besi maka seng merupakan bahan alternatif untuk berikatan dengan protoporfirin sehingga terjadi peningkatan kadar ZPP. ${ }^{15}$ Lind T dkk, ${ }^{9}$ meneliti efek pemberian besi dan seng serta gabungan besi dan seng kemudian membuktikan bahwa kombinasi besi dan seng berkurang efikasinya dalam meningkatkan status besi dan seng.

Pada penelitian ini dampak seng tidak bermakna dalam meningkatkan kadar hemoglobin dan serum feritin. Tampaknya seng mempengaruhi absorbsi besi karena pada proses absorbsi besi di bagian apikal enterosit oleh DMT-1 ternyata juga dapat dilalui oleh seng ${ }^{9}$. Mungkin saja pemberian seng akan mempengaruhi penyerapan besi pada sel-sel usus walaupun tidak menghambat secara sempurna.

INACG (International Nutritional Anemia Consultative Group) bekerjasama dengan WHO dan UNICEF melakukan pembahasan terhadap informasi terbaru dari data beberapa penelitian. Terdapat peningkatan status hematologi terhadap suplementasi besi secara oral sehingga layak untuk diterapkan pada daerah endemis malaria. ${ }^{24}$ Yulizar $^{25}$, menemukan bahwa gambaran hemogram pada anak yang menderita malaria falciparum meningkat secara bermakna setelah suplementasi besi selama empat minggu di daerah yang sama dengan penelitian ini.

Pada penelitian sebelumnya tampak efek kompetitif antara besi dan seng jika mikronutrien tersebut digabung dalam bentuk sirup. ${ }^{9}$ Pada penelitian ini diberikan sirup berisi sulfa ferosus agar mudah dalam pemberian dan lebih menarik bagi anak dan orangtua sedangkan seng diberikan terpisah dalam bentuk kaplet. Ketika konsentrasi serum feritin turun sampai di bawah $50 \mu \mathrm{g}$ per liter, pemberian besi untuk pencegahan dapat diberikan, tetapi bila kadarnya lebih dari 100 $\mu \mathrm{g}$ per liter maka pemberian besi tidak dibutuhkan. ${ }^{26}$ Sebaiknya diperiksa konsentrasi serum feritin pada anak di daerah endemis malaria sebelum diberikan suplementasi besi untuk mencegah kelebihan besi tetapi di negara berkembang hal ini sulit dilakukan karena biaya yang mahal dan keterbatasan pemeriksaan serum feritin. 
Berdasarkan penelitian ini, kami juga menganjurkan bahwa suplementasi besi untuk malaria asimtomatik dengan konsentrasi serum feritin yang normal atau tinggi tidak dibutuhkan sebagai pencegahan terhadap anemia yang disebabkan oleh malaria. Menurut beberapa literatur pemeriksaan retikulosit baik digunakan menilai respon awal terhadap suplementasi besi. Pada penelitian ini respon tersebut belum bermakna karena hanya diperiksa jumlah retikulosit pada sebelum suplementasi dan 30 hari sesudah suplementasi. Sebaiknya diperiksa juga jumlah retikulosit pada sebelum suplementasi serta hari ke3, hari ke-5, dan hari ke-10 setelah suplementasi. Sebaiknya juga dilakukan pemeriksaan serum transferin receptor karena pemeriksaan dapat digunakan untuk mendeteksi defisiensi besi secara dini. Pemeriksaan ini tidak dipengaruhi oleh proses inflamasi akut atau kronik sehingga baik digunakan pada daerah dengan prefalensi infeksi yang tinggi. ${ }^{27}$

\section{Daftar pustaka}

1. Iyer JK, Shi L, Shankar AH, dkk. Zinc protoporphyrin IX binds heme crystal to inhibit the process of crystallization in Plasmodium falciparum. Molecular Med 2003; 9:175-82.

2. The Zinc Against Plasmodium Study Group. Effect of zinc on the treatment of Plasmodium falciparum malaria in children: a randomized controlled trial. Am J Clin Nutr 2002; 76:805-12.

3. Hastka J, Lasserre JJ, Schwarzbeck A. Central role of zinc protoporphyrin in staging iron deficiency. Clin Chem 1994; 40/5:768-73.

4. Brabin BJ. The role of malaria in nutritional anemias. Dalam: Fomon SJ, Zlotkins S, penyunting. Nutritional Anemias. Newyork: Nestec/Raven Press; 1992. h. 65-80.

5. Fomon SJ. Iron. Dalam: Fomon SJ, penyunting. Infant nutrition. Edisi ke-2. Philadelphia: Saunders; 1974. h. 299-317

6. Rettmer RL, Timothy $\mathrm{H}$, Origenes ML. Zinc protoporphyrin/heme ratio for diagnosis of preanemic iron deficiency. Pediatrics 1999; 104:37-41.

7. Will AM. Iron metabolism, sideroblastic anemia and iron overload. Dalam: Lilleyman JS, Hann IM, Blanchette VS, penyunting. Pediatric hematology. Edisi ke-2. London: Churchill Livingstone; 2000. h. 105-26.

8. Verhoef H, West CE, Nzyuko SM. Intermittent administration of iron and sulfadoxine-pyrimethamine to controle anaemia in Kenyan children: a randomized controlled trial. Lancet 2002; 360:984-14.

9. Lind T, Lonnerdal B, Stenlund H, dkk. A communitybased randomized controlled trial of iron and zinc supplementation in Indonesian infants: interactions between iron and zinc. Am J Clin Nutr 2003; 77: 88390.

10. Kuczmarski RJ, Ogden CL, Guo SS, dkk. 2000 CDC growth chart for the United State: Methods and development. National Center for Health Statistics. Vital Health Stat 11(246). 2002. Diunduh dari: http//www.cdc. gov/growthcharts

11. Verhoef H, Rijlaarsdam, Burema J. Infection and malnutrition in African children. Dalam: Verhoef $\mathrm{H}$, penyunting. Iron deficiency and malaria as determinants of anaemia in African children. Disertasi. Wageningen: Wageningen University; 2001. h. 10-45.

12. Caulfield LE, Richard SA, Black RE. Under nutrition as an underlying cause of malaria morbidity and mortality in children less than five years old. Am J Trop Med Hyg 2004; 71(Suppl 2): 55-63.

13. Genton B, Al-Yaman F, Ginny M, Taraika J, Alpers MP. Relation of anthropometry to malaria morbidity and immunity in Papua New Guinean children. Am J Clin Nutr 1998; 68: 734-41.

14. Shankar AH. Nutritional modulation of malaria morbidity and mortality. J Infect Dis 2000; 182 (suppl1): S37-S53.

15. Labbe RF, Vreman HJ, Stevenson DK. Zinc protoporphyrin: A metabolite with a mission. Clin Chem 1999; 45: 2060-72.

16. Dallman PR, Yip R, Oski FA. Iron deficiency and related nutritional anemias. Dalam: Nathan DG, Oski FA, penyunting. Hematology of infancy and childhood. Edisi ke-4. Philadelphia: Saunders; 1993. h. 413-46.

17. Sandoval C, Jayabose S, Eden AN. Trends in diagnosis and management of iron deficiency during infancy and early childhood. Hematol Oncol Clin N Am 2004; 18 : 1423-1438.

18. Haematopoiesis. Dalam: Hoffgrand AV, Petit JE, penyunting. Kapita selekta haematologi. Edisi ke-2, EGC; 1996, h.1-27.

19. Schwartz E. Anemia of chronic disorder and renal diseases. Dalam: Behrman RE, Kligman RM, Arvin AM, penyunting. Nelson text book of pediatric, Edisi ke-16. Philadelphia : Saunders; 2000. h. 1461-2.

20. Oski FA. Nutritional anemias. Dalam: Walker WA, Watkins JB, penyunting. Nutrition in pediatrics basic science and clinical application. Edisi ke-1. Toronto: 
Little Brown; h. 107-26.

21. Brugnara C, Zurakowski D, DiCanzio J, Boyd T, Platt O. Reticulocyte hemoglobin content to diagnose iron deficiency in children. JAMA 1999; 281: 2225-30.

22. Stoltzfus RJ, Chwaya HM, Albonico M, Schultze KJ, Savioli L, Tielsch JM. Serum feritin, erythrocyte protoporphyrin and hemoglobin are valid indicators of iron status of sshool children in a malaria-holoendemic population. J. Nutr 1997; 127:293-8.

23. O'Brien RT. Hematologic manifestation of chronic systemic disease. Dalam: Miller DR, Baehner RL, penyunting. Blood diseases of infancy and childhood. Edisi ke-7. St Louis: Mosby; 1995. h. 539-41.

24. INACG Expert Panel. Safety of iron supplementation programs in malaria-endemic regions. INACG consensus statement. Washington: International Nutritional Anaemia Consultative Group, 1999.

25. Yulizar. Manfaat suplementasi besi pada penderita malaria falciparum yang mendapat pengobatan anti malaria dengan parameter gambaran hemogram. Tesis. Sumatera Utara University, Medan, Indonesia, 2003

26. Griffin IJ, Reid MM, McCormick KPB, Cooke RJ. Zinc protoporphyrin/haem ratio and plasma ferritin in preterm infants. Arch Dis Child Fetal Neonatal 2002; 87: F49-F51.

27. Olivares M, Walter T, Cook JD, Hertrampf E, Pizarro F. Usefulness of serum transferrin receptor and serum ferritin in diagnosis of iron deficiency in infancy. Am J Clin Nutr 2000; 72: 1191-5. 